\title{
Hagiography and Charters in Early Northumbria*
}

\author{
David A. Woodman
}

If you walk into St Paul's church in Jarrow today, you will see a lateseventh-century Northumbrian inscription recording the dedication of the church on 23 April, 685 (see Figure 4.I). It has been incised on two stones, and, with the abbreviations expanded and word divisions inserted, the upper stone reads:

[chi-rho] DEDICATIO BASILICAE

SANCTI PAVLI VIIII KALENDAS MAIAS

ANNO XV ECFRIDI REGIS

and the lower stone reads:

CEOLFRIDI ABBATIS EIVSDEMQUE ECCLESIAE DEO AUCTORE CONDITORIS ANNO IIII ${ }^{\text {I }}$

Higgitt has shown how these inscriptions demonstrate Jarrow's romanitas at this early stage in its history: the language of the inscriptions may find inspiration from documents of the papal chancery, ${ }^{2}$ while the way in which the letters are formed can be closely compared with capitals in the Codex Amiatinus. ${ }^{3}$ These similarities demonstrate collaboration between those at

\footnotetext{
* It is not possible adequately to express my gratitude to Simon Keynes, both professionally and personally. From the moment I was interviewed in December 1998 for an undergraduate place to read Anglo-Saxon, Norse and Celtic at Trinity College, Cambridge, he has shown the greatest generosity, and latterly friendship, to me. Were it not for his inspirational example as a teacher and scholar, I would not be attempting to pursue an academic path. In this chapter I am drawing on research done and ideas formulated during the writing of my MPhil and PhD dissertations, the first of which was examined by Simon Keynes and the second of which was supervised by him. It therefore seems a particularly appropriate offering for the honorand of this volume.

I 'The dedication of the church of St Paul [was] on 23 April in the fifteenth year of King Ecgfrith and the fourth year of Ceolfrith the abbot and, under God's guidance, founder of this same church.' E. Okasha, Hand-List of Anglo-Saxon Non-Runic Inscriptions (Cambridge, I97I), pp. 85-6 (no. 6I); cf. R. Cramp, Wearmouth and Jarrow Monastic Sites, 2 vols. (Swindon, 2005), esp. vol. I, pp. 365-6.

2 J. Higgitt, 'The Dedication Inscription at Jarrow and Its Context', AntJ 59 (1979), 343-74, at 350 and 364.

3 Ibid., pp. $358-9$ and $362-3$.
} 


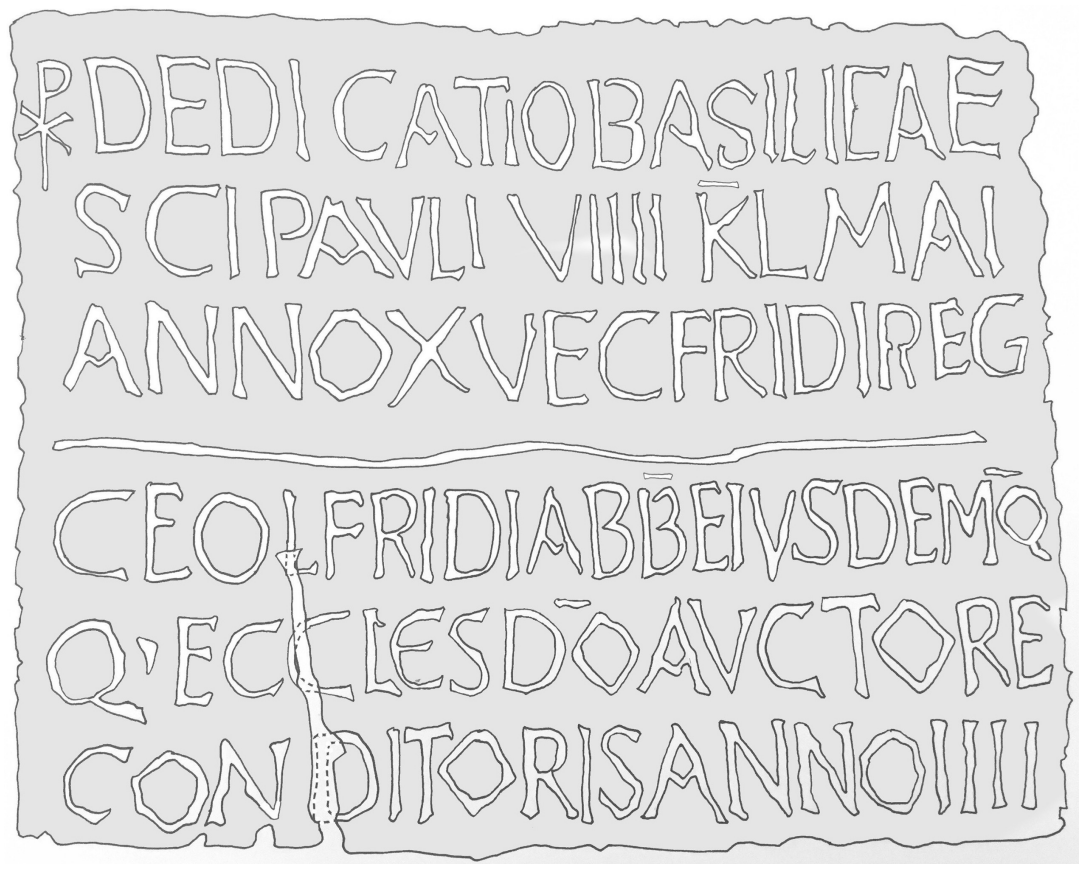

Figure 4.I Jarrow dedication stone. (By Bob Naismith.)

Jarrow responsible for the writing of texts and those tasked with the composition of a dedication inscription. But it is also worth noting that the chi-rho used, although typical of early Italian models, ${ }^{4}$ is also employed as a pictorial invocation at the beginning of various Anglo-Saxon diplomas. ${ }^{5}$ And the use of the regnal year in the dating of the inscription can likewise be paralleled in Anglo-Saxon diplomatic. ${ }^{6}$ Similar evidence of cross-fertilisation or generic 'mixing' can be seen in the case of Anglo-Saxon charters.

In the seventh century, Anglo-Saxon ecclesiastics saw the value in having a form of written proof of ownership so that lands could be held free from

4 Ibid., p. 349.

5 Higgitt compares the Jarrow chi-rho to that found in two late-eighth-century Mercian diplomas: ibid., p. 349.

${ }^{6}$ One should compare here the chapter of the Life of Ceolfrith that records the beginning of the building of the Wearmouth church using a dating-clause that employs an indiction, a regnal year and an anno Domini date. The same chapter states that this church was given fifty hides of land by King Ecgfrith. Both the dating-clause and the grant of land are written in terms reminiscent of charter diplomatic. See the Vita Ceolfridi, chap. 7, in Abbots of Wearmouth and Jarrow, ed. and trans. C. Grocock and I. N. Wood (Oxford, 20I3), pp. 84-6. 
certain financial obligations and could be passed from generation to generation. These were some of the reasons that charters were first introduced in England, as instruments of the Church. ${ }^{7}$ S 8 (CantCC 2), issued in 679 by King Hlothhere of Kent and celebrated as the earliest extant original Anglo-Saxon diploma, opens with a divine invocation ('In nomine Domini nostri saluatoris Iesu Christi'). It is therefore interesting that the words with which Stephen opens his account of St Wilfrid's life, the Vita Wilfrithi (hereafter $V W$ ), are 'In nomine Domini nostri Christi Iesu' ('In the name of our Lord Christ Jesus'). ${ }^{8}$ Did Stephen have in mind the wording of a diploma? At the outset of his work, was he trying to suggest that his vita aspired to the formal status of a legal document? The question is worth asking in the light of the circumstances in which the $V W$ was composed.

\section{Lindisfarne and the Anonymous Vita sancti Cuthberti}

Anglo-Saxon Northumbria was the kingdom where many of the most celebrated early religious houses were situated. Some of these institutions enjoyed fame across contemporary Europe and maintained links with other European houses. But, despite the political and ecclesiastical reputation of Northumbria, there were signs of discord and internal divisions. ${ }^{9}$ In 664, the Council of Whitby had shown this very publicly, and it was here that Wilfrid, in Bede's Historia ecclesiastica, was celebrated as the champion of the Roman method of calculating the date of Easter. ${ }^{\text {IO }}$ The departure of Wilfrid's principal opponent at the Council of Whitby, Colman, indicated the kind of discontent that remained for those at Lindisfarne who still

\footnotetext{
7 For the introduction of the Anglo-Saxon charter, see P. Chaplais, 'Who Introduced Charters into England? The Case for Augustine', Journal of the Society of Archivists 3. IO (1969), 526-42, reprinted in Prisca Munimenta, ed. F. Ranger (London, 1973), pp. 88-107; S. Kelly, 'Anglo-Saxon Lay Society and the Written Word', in The Uses of Literacy in Early Mediaeval Europe, ed. R. McKitterick (Cambridge, 1990), pp. 37-62, at 40-2; S. Keynes, 'Church Councils, Royal Assemblies and AngloSaxon Royal Diplomas', in Kingship, Legislation and Power in Anglo-Saxon England, ed. G. R. Owen-Crocker and B. W. Schneider (Woodbridge, 2013), pp. I7-139, at 19-20; and B. Snook, 'Who Introduced Charters into England? The Case for Theodore and Hadrian', in Textus Roffensis: Law, Language, and Libraries in Early Medieval England, ed. B. R. O'Brien and B. Bombi (Turnhout, 2015), pp. 257-90.

${ }^{8}$ VW preface, in The Life of Bishop Wilfrid by Eddius Stephanus, ed. and trans. B. Colgrave (Cambridge, 1927), pp. 2-3.

9 C. Cubitt, 'Wilfrid's "Usurping Bishops": Episcopal Election in Anglo-Saxon England, c. 6ooc. 80o', NH 25 (1989), I8-38.

Io Bede, Historia ecclesiastica [hereafter $H E$ ] iii. 25, in Bede's Ecclesiastical History of the English People, ed. B. Colgrave and R. A. B. Mynors (Oxford, 1969), pp. 294-309.
} 
favoured Irish modes of religious observance. ${ }^{\text {II }}$ Although Bede in his Historia ecclesiastica attempts to depict a scene of relative religious unity, his private letter to Bishop (and later Archbishop) Ecgberht indicates that the reality was far from harmonious, as nobles abused charters to found fake monasteries as an early kind of tax evasion and ecclesiastics everywhere failed to uphold their religious duties. ${ }^{\text {I2 }}$ One reason that Bede provided a picture of a unified Church in his Historia ecclesiastica is that he hoped to present a model for his contemporaries so that Christianity could thrive. But there were any number of potential obstacles to such a plan as political structures fragmented or religious communities had different modes of worship and found themselves in competition with one another for limited amounts of land, resources and patronage. Any breakdown in political or religious authority also afforded the opportunity for a reshuffling of personnel, and at various moments in this early period of Northumbrian history different ecclesiastics were moved from (control of) one ecclesiastical house to another or removed entirely depending on whether or not they (or their patrons) were in favour. Wilfrid's ecclesiastical career arguably typifies this pattern more than any other, for he found himself both in and out of favour and sought to impose himself over various ecclesiastical communities. By the time of his death in 7Io, his life had involved many controversial episodes. ${ }^{13}$

It is against this background that an early sequence of Northumbrian vitae emerges into view in the late seventh and early eighth centuries, some championing Cuthbert of Lindisfarne and one championing Wilfrid of Ripon. ${ }^{14}$ These texts are very significant: not only are they some of the

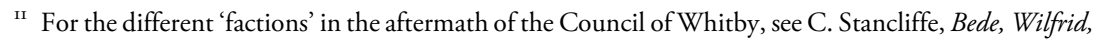
and the Irish, Jarrow Lecture 2003 (Jarrow, 2004), pp. IO-II.

I2 Bede, Epistola ad Ecgbertum, in Abbots, ed. Grocock and Wood, pp. 124-6I. For Bede's concerns (and proposed solutions), see A. Thacker, 'Bede's Ideal of Reform', in Ideal and Reality in Frankish and Anglo-Saxon Society, ed. P. Wormald, with D. Bullough and R. Collins (Oxford, I983), pp. I30-53, at $132-3$.

${ }^{13}$ For an important collection of work about Wilfrid, see N. J. Higham (ed.), Wilfrid: Abbot, Bishop, Saint; Papers from the 130oth Anniversary Conferences (Donington, 2013); for the dating of significant events in Wilfrid's life, see C. Cubitt, 'St Wilfrid: A Man for his Times', ibid., pp. 3II-47, at 342-7.

${ }^{\mathrm{I}}$ An anonymous Lindisfarne prose vita of Cuthbert [hereafter $V C A$ ] was composed some time between 699 and 705 (see B. Colgrave, Two Lives of Saint Cuthbert (Cambridge, 1940), p. 13). About ten years after publication of the VCA, Stephen produced the VW: B. Colgrave, The Life of Bishop Wilfrid by Eddius Stephanus (Cambridge, 1927); for recent comments about the date at which this vita was written, see C. Stancliffe, 'Dating Wilfrid's Death and Stephen's Life, in Wilfrid: Abbot, Bishop, Saint, ed. Higham, pp. 17-26, where a date of $c .713$ is suggested; see also D. P. Kirby, 'Bede, Eddius Stephanus and the "Life of Wilfrid"', $E H R 98$ (1983), IOI-I4. The $V C A$ was later supplemented by a metrical version of the vita written by Bede, which was finished in the period $704 \times 716$ but probably nearer 704 and possibly revised at a later stage (see M. Lapidge, 'Bede's Metrical Vita S. Cuthberti', in St Cuthbert: His Cult and Community to A.D. I20o, ed. 
earliest examples of Anglo-Saxon hagiography, but they were written by members of religious communities that were at times in competition with each other. ${ }^{\text {Is }}$ It would be incorrect to imagine that the early Northumbrian Church was divided simply between the followers of Cuthbert and Wilfrid, since there were manifold influences on early Northumbria, from those of the native British to those of the Franks. ${ }^{16}$ But it was these two communities, Lindisfarne and Ripon, that pursued their differences by means of texts. It is important to understand why and how they did so and to demonstrate the ways in which they describe and depict their subjects, Cuthbert and Wilfrid, for two very different characters emerge from any such reading. These differences are all the more interesting given that these early vitae have long been known to be responding to one another in a kind of 'hagiographic feud'. This chapter does not differ from established scholarly orthodoxy about the interactions of these Northumbrian vitae but seeks instead in a small way to supplement it, by offering a close reading of the $V C A$ and $V W$ in particular and highlighting some of the ways in which they were responding to one another. ${ }^{17}$

In the atmosphere of competition between Northumbrian religious houses, ${ }^{18}$ one of Lindisfarne's reactions was to commission the writing by one of its community of a prose vita in honour of Cuthbert, the $V C A$. In

G. Bonner, D. W. Rollason and C. Stancliffe (Woodbridge, I989), pp. 77-94). Finally, at some point $c$. 72I, to accompany his recently finished metrical version, Bede produced a new prose vita that based itself on the VCA but also added new material (D. P. Kirby, 'The Genesis of a Cult: Cuthbert of Farne and Ecclesiastical Politics in Northumbria in the Late Seventh and Early Eighth Centuries', JEH 46 (1995), 383-97, at 385-6; in this new prose vita, Bede states that he gained this new material from conversations with the priest Herefrith).

is For very useful comments about the nature of the relationships between these early Northumbrian communities, see I. N. Wood, 'Monasteries and the Geography of Power in the Age of Bede', NH 45 (2008), II-25.

16 For an overview of such influences, see D. Rollason, Northumbria, 500-II00: Creation and Destruction of a Kingdom (Cambridge, 2003), pp. IIO-70. See also I. N. Wood, 'Northumbrians and Franks in the Age of Wilfrid', $\mathrm{NH}_{3 \mathrm{I}}$ (I995), IO-2I.

${ }_{7}$ Nothing is said about the later vitae written by Bede, which have recently been discussed by C. Stancliffe, 'Disputed Episcopacy: Bede, Acca, and the Relationship between Stephen's Life of St Wilfrid and the Early Prose Lives of St Cuthbert', ASE 4I (20I2), 7-39. See also W. Goffart, The Narrators of Barbarian History (A.D. 550-800): Jordanes, Gregory of Tours, Bede, and Paul the Deacon (Princeton, NJ, 1988), pp. 235-328 (at 262-3 for useful comments about the Cuthbertine and Wilfridian factions); and A. Thacker, 'Lindisfarne and the Origins of the Cult of St Cuthbert', in St Cuthbert, ed. Bonner et al., pp. I03-24. For discussion of some of the changes effected by Bede in his rewriting of the vita of Cuthbert, with a particular focus on place-names, see A. Joseph McMullen, 'Rewriting the Ecclesiastical Landscape of Early Medieval Northumbria in the Lives of Cuthbert', ASE 43 (2014), 57-98.

${ }^{18}$ For the effects of this competition on the burial practices with regard to Northumbrian kings, see B. Yorke, 'The Burial of Kings in Anglo-Saxon England', in Kingship, Legislation and Power, ed. OwenCrocker and Schneider, pp. 237-57, at 248-9. 
any reading of the $V C A$, it is important to remember that this was composed with the 'ghost of Wilfrid' in the background. ${ }^{19}$ Some scholars have judged the $V C A$ in rather negative terms, particularly when compared with the later prose vita written by Bede, suggesting that it possesses a kind of chronicle-like simplicity in which accounts of miracles are heaped up without any narrative development. ${ }^{20}$ Actually, however, there is greater sophistication than first appears in terms of the $V C A$ 's content and structure. It opens with a prologue that demonstrates a programmatic fondness for a very similar kind of inter-textual relationship to that mentioned earlier. The prologue borrows from different sources, including the Evagrian Vita Antonii, the Vita Martini by Sulpicius Severus, the Actus Silvestri and a letter drawn up c. 450 introducing the paschal cycle by Victorius of Aquitaine and addressed to Hilarus, who was elected pope in $46 \mathrm{I}^{2 \mathrm{I}}$

Of these sources, the Vita Martini seems to have had an important influence on the $V C A$, whose first two chapters in effect constitute a double preface of the sort initiated by Sulpicius Severus. ${ }^{22}$ Two chapters of the VCA borrow from the Vita Martini, and many other episodes, as Thacker has shown, have their counterpart in Sulpicius' account. ${ }^{23}$ Sulpicius had

is This phrase is borrowed from Goffart, The Narrators.

${ }^{20}$ See, for example, Colgrave, Two Lives, p. I6; and C. E. Newlands, 'Bede and Images of Saint Cuthbert', Traditio 52 (1997), 73-I09, at 83-4.

${ }^{21}$ For this opening passage, see B. Colgrave, 'The Earliest Saints' Lives Written in England', PBA 44 (1958), 35-60, at 42-4; and B. Colgrave, Two Lives, pp. 60-5 and 310-II. For the motivations of the Lindisfarne author in borrowing from such earlier Vitae, see M. Lapidge, 'The Saintly Life in AngloSaxon England', in The Cambridge Companion to Old English Literature, ed. M. Godden and M. Lapidge, 2nd edn (Cambridge, 20I3), pp. 25I-72, at 262. For more about this prologue, where new sources are identified, see Stancliffe, 'Disputed Episcopacy', pp. I2-I4, where it is shown that the $V C A$, by certain borrowings, 'reveals itself as standing in the same tradition as saints' Lives written by Irish adherents of the Roman Easter' (at I4).

${ }^{22}$ For the particular influence of Sulpicius' writing on the author of the VCA, see Thacker, 'Bede's Ideal', pp. 136-7; and Thacker, 'Lindisfarne', pp. IIO-I2. The Vita Antonii by Athanasius formed a significant model for Sulpicius Severus when he was writing his Vita Martini. Sulpicius observed in Athanasius' work what appeared to him to be a double preface (in fact, the second part of the preface was added as a kind of translator's note when Evagrius made his translation into Latin), so the presence of a 'double preface' in an Insular Vita suggests that the Vita in question was modeling itself on the Vita Martini. See further, J.-M. Picard, 'Structural Patterns in Early Hiberno-Latin Hagiography', Peritia 4 (1985), 67-82; C. Stancliffe, St Martin and His Hagiographer. History and Miracle in Sulpicius Severus (Oxford, 1983), pp. 73-4; and S. Coates, 'The Bishop as Pastor and Solitary: Bede and the Spiritual Authority of the Monk-Bishop', JEH 47 (I996), 6oI-I9.

${ }^{23} V C A$ i. 2 and iv. I (ed. Colgrave, pp. 62-4 and IIO-I2) borrow from the Vita Martini. Thacker, 'Lindisfarne', pp. IO9-I5, discusses the range of different influences on the VCA (at pp. IIO-II, Thacker describes the $V C A$ as 'distinctly innovatory in structure' and suggests that this structure derives from the pattern established by Sulpicius). For further comments on the VCA's use of sources in general, not just the Vita Martini, see also C. Stancliffe, 'Cuthbert and the Polarity between Pastor and Solitary', in St Cuthbert, ed. Bonner et al., pp. 2I-42, at 25-7. 
dedicated his work to Desiderius, an Aquitanian in the same ascetic circles as Sulpicius, and at the end, Sulpicius closes by hoping that his book will bring pleasure to omnibus sanctis. ${ }^{24}$ Published just before Martin's death, the Vita Martini was launched at a time of great ecclesiastical dissension, ${ }^{25}$ when the Gallo-Roman episcopate displayed particular hostility to the ascetic movement. As part of his response to this threat, Sulpicius, throughout his vita, promotes and defends the ascetic life that Martin had led, even as a bishop. ${ }^{26}$ What is continually stressed is that Martin is a true monk and a true bishop and that neither role is exclusive of the other. ${ }^{27}$ Martin may use his ascetic virtue to win him favours from God, but these favours are invariably used to help people and to fulfil his pastoral duty. In championing the ideal of a 'monk-bishop', ${ }^{28}$ Sulpicius was producing a kind of ascetic propaganda and thus an indirect attack on the worldly bishops of Gaul.

It seems very likely that, by alluding to the work of Sulpicius, the author of the $V C A$ was attempting to characterise Cuthbert in the same manner as Martin and hence to confirm that Cuthbert could also be a kind of 'monkbishop'. ${ }^{29}$ And it is further probable that this was a response to the character of one of the Lindisfarne community's principal opponents, Wilfrid, who at times seemed more akin to a secular lord than a devout

${ }^{24}$ VM, chap. 27.6, in Vie de Saint Martin, ed. and trans. J. Fontaine, Sources chrétiennes I33-5, 3 vols. (Paris, I967-9), vol. I, pp. 316-I7. Sulpicius' prologue evokes the opening words of Sallust's Bellum Catilinae, perhaps in an attempt to address and appeal to all readers, not just ascetics. The part of Sallust to which Sulpicius refers stresses man's transience in the world and suggests that, to overcome this, a man has to strive to attain everlasting fame, founded on virtus, by deeds or words. However, Sulpicius proceeds to undermine Sallust and to assert instead the Christian ideal, 'For what use to them was the acclaim, which will vanish with this world, accorded to their writings?' ('Quid enim aut ipsis occasura cum saeculo scriptorum suorum gloria profuit?') (VM I.3, ed. and trans. Fontaine I, 250-I). The reader is to realise that eternal life, achieved through living religiously rather than as a pagan, was preferable to eternal fame. Sulpicius was correcting his classical models and refashioning them to suit his aim: an account of a Christian soldier attempting to win eternal life. For the influence of classical biography on the Vita Martini, see Stancliffe, St Martin, pp. 58-6I, 7I-80 and 86-IO2, esp. 89-90; Picard, 'Structural Patterns', pp. 70-I; and G. B. Townend, 'Suetonius and His Influence', in Latin Biography, ed. T. A. Dorey (London, 1967), pp. 79-III.

25 Stancliffe, St Martin, p. $86 . \quad{ }^{26}$ Ibid., pp. 7I-80.

27 For Martin's continued monastic way of life while bishop, see Thacker, 'Bede's Ideal', pp. I36-7; and Stancliffe, 'Cuthbert', p. 38.

28 Stancliffe, St Martin, p. 95.

29 For Thacker, 'Bede's Ideal', p. I48, 'the parallels with Martin of Tours, for example, suggest that Cuthbert was already being promoted as the Northumbrian equivalent of the Gaulish Reichsheiliger'. Coates, 'The Bishop', pp. 613-I4, demonstrates that the VCA's reliance on Martinian models resembled contemporary Irish interests and that 'since Iona was the mother church of Lindisfarne the anonymous Life displayed close links with Adomnán's Life of Columba' (at 6I3). See also Thacker, 'Lindisfarne', pp. II2-I3; and Stancliffe, 'Cuthbert', pp. 22-3. 
cleric. $^{30}$ The structure of the $V C A$ is carefully arranged in order to help create this image of Cuthbert. It is divided into four books, ${ }^{3 \mathrm{I}}$ of which the first three deal, respectively, with Cuthbert's childhood, his time as pastor and prior and his life as a hermit on Inner Farne, while the fourth, the longest of all the books, talks of Cuthbert's time as a bishop and a little about his posthumous cult. They are arranged in such an order that they highlight Cuthbert's achievement in combining the ascetic lifestyle with his episcopal office, in the true Martinian sense. As would be expected, the words employed to describe Cuthbert underline this structure of the work as a whole, since he moves from being described as homo Dei or seruus Christi in books two and three until he finally becomes sanctus episcopus in book four.

Although Cuthbert is ultimately depicted as being reluctant to take up episcopal office, his elevation to the rank of bishop was a principal issue around which the anonymous author constructed his account; this is made clear at several points in the vita. In the preface he announces that he 'will therefore undertake to write the life of St Cuthbert and how he lived both before and after he became bishop'. ${ }^{32}$ The very first chapter after the preface continues this theme. A young boy, scarcely three years old, finds Cuthbert indulging in idle play with other children and frantically urges Cuthbert to stop. Being able to stand it no longer, the boy exhorts Cuthbert, 'O holy Bishop and priest Cuthbert $[O$ sancte episcope et presbiter Cuðberhte], these unnatural tricks done to show off your agility are not befitting to you or your high office'. ${ }^{33}$ Here, in our first encounter with Cuthbert, he is described as episcope, a term that is not used again until book four. The Lindisfarne author, at the very beginning of his work, is highlighting a major theme he wishes to develop, that Cuthbert was simultaneously sanctus and episcopus even early in life. ${ }^{34}$ Two chapters

30 For the VCA's depiction of Cuthbert as a bishop who did not abandon a monastic way of life, see Thacker, 'Lindisfarne', p. III; and Stancliffe, 'Cuthbert', pp. 35-6 (and further pp. 36-42 for the image (and its models) of Cuthbert as both 'pastor and solitary' in accounts of his life).

${ }^{31}$ Thacker, 'Lindisfarne', p. III, suggests that this division into four books 'harks back to Martinian exempla'.

32 VCA i. 2 (ed. and trans. Colgrave, pp. 62-3). Incidentally, it is noticeable that at this very moment when the Lindisfarne author wishes to place an emphasis on the importance of Cuthbert as bishop, he borrows a passage from Sulpicius; see Colgrave, Two Lives, p. 62.

33 VCA i. 3 (ed. and trans. Colgrave, pp. 64-5). For discussion of this passage, see Thacker, 'Lindisfarne', p. III; Stancliffe, 'Disputed Episcopacy', pp. 20-I.

34 And, as Stancliffe has shown, this passage is likewise designed to demonstrate 'Cuthbert's predestination as one of God's elect from infancy': Stancliffe, 'Disputed Episcopacy', p. 2o. For comments about the nature of ecclesiastical life at this time, see J. Campbell, 'Elements in the Background to the Life of St Cuthbert and his Early Cult', in St Cuthbert, ed. Bonner et al., pp. 3-19. 
later, Cuthbert is given encouragement to pursue his destiny when he is overjoyed by witnessing 'the soul of a most holy bishop or of some other great person' being borne to heaven by angels. ${ }^{35}$ Later he realises that this bishop was none other than Aidan himself. Subsequent events in the first three books demonstrate Cuthbert's ability as a miracle-worker. These not only guarantee Cuthbert's status as sanctus but depict him as the ideal pastor and episcopus. For example, Cuthbert was invited by the nun Æbbe to visit the monastery of Coldingham. He agrees to go but 'did not relax his habitual way of life'. He continues his ascetic lifestyle and endures a period of penitence in the ice-cold sea. When he returns from the water, he has his feet washed by 'two little sea animals, humbly prostrating themselves on the earth ... wiping them [his feet] with their skins and warming them with their breath, ${ }^{36}$ demonstrating that through his extreme asceticism he has been granted the respect and reverence even of animals. But at this very moment, when Cuthbert's individual sanctity is stressed, we learn that 'the man of God, returning home at cockcrow, came to the church of God to join in public prayer with the brethren' (Ille iam homo Dei in galli cantu reuertens ad orationem communem cum fratribus ad aecclesiam Dei). Cuthbert, both sanctus and episcopus, always has a mind for his brethren and familia.

A major event in Cuthbert's life occurs at the very beginning of book four when he becomes bishop. At this crucial stage in the work, Cuthbert 'graduates' from being a homo Dei or a seruus Christi to sanctus episcopus noster. Thus the very first words that had been used to describe Cuthbert have eventually come full circle and fulfilled the young boy's prophecy at the beginning of the vita that he would become episcopus. And this transition is further underlined by the Lindisfarne author. At the end of the first and fourth books, the Lindisfarne author uses carefully selected verbs, sanauit ('he healed') and sanatus sit ('[he] was healed'). These verbs connect the first and last books by means of ring composition and frame the two middle books which describe Cuthbert's journey towards becoming bishop. The ring composition is further underlined by the etymology involved: sanctus ('holy') is the past participle of sancire ('to confirm'), which was thought to be etymologically connected (through their common derivation from sanguis) with sanus ('healthy'). ${ }^{37}$

\footnotetext{
35 'Animam ... sanctissimi episcopi, aut alterius magne persone' (VCA i. 5 (ed. and trans. Colgrave, pp. 68-9)). His destiny had been made explicit by the anonymous author in i. 3: 'Behold, brethren, how even before he is recognised by the performance of his works, he is shown by the providence of God to be elect' ('videte fratres quomodo iste antequam per laborem operum suorum agnoscatur, per prouidentiam Dei electus ostenditur').

${ }_{36}$ VCA ii. 3 (ed. and trans. Colgrave, pp. 80-I).

37 R. Maltby, A Lexicon of Ancient Latin Etymologies (Leeds, I99I), pp. 542-3.
} 
The Lindisfarne author has taken pains to emphasise Cuthbert's development from the first book to the last, where he attains the bishopric. ${ }^{38}$ In the uncertain religious-political context of the late seventh and early eighth centuries, where religious houses were jostling for episcopal status and an immensely powerful individual such as Wilfrid could emerge as bishop, it was especially important for Lindisfarne to depict its community as being worthy of its see; the portrait of Cuthbert as a holy 'monk-bishop' was an astute response to decidedly turbulent times. ${ }^{39}$

\section{Ripon and the Vita sancti Wilfrithi}

Some ten years after the composition of the $V C A$, the priest Stephen produced his $V W .^{4 \circ}$ Even a superficial reading of the $V W$ demonstrates just how different its form and content are to the $V C A$; in fact, the two appear to have wholly disparate concerns. ${ }^{4 \mathrm{I}}$ The $V W$ minimises the miraculous (while the VCA describes thirty miracles of Cuthbert, the $V W$ has only ten) and depicts Wilfrid as a wealthy, powerful and almost secular-like figure (features noticeably absent from the $V C A$ ). ${ }^{42}$ Stephen's text also

${ }^{38}$ For more about the structure of the VCA, see J. C. Eby, 'Bringing the Vita to Life: Bede's Symbolic Structure of the Life of St Cuthbert', American Benedictine Review 48 (1997), 316-38, at 323.

39 For recent comments placing all these early Northumbrian vitae in their appropriate religiouspolitical setting, see Stancliffe, 'Disputed Episcopacy'. Coates, 'The Bishop', pp. 6oI-I9, considers in detail the characterisation of bishops by Bede, demonstrating the importance of 'continued attachment to ascetic traditions once they had been elevated to the episcopate ... He [Bede] presented bishops as ascetic giants' (at p. 602). For the importance of the work by Sulpicius Severus in championing Martin as someone who successfully combined asceticism with his episcopal responsibilities, see ibid., pp. 606-7, and for the depiction of Cuthbert in the VCA, see ibid., pp. 6I2-I5, where Coates argues that the anonymous author has a rather 'negative view of episcopal office' (at p. 613).

${ }^{40}$ For the date of composition of the $V W$, see the work by Stancliffe, cited earlier, n. I4.

${ }^{41}$ For the biblical imagery and typology in Stephen's VW, see W. T. Foley, Images of Sanctity in Eddius Stephanus' 'Life of Saint Wilfrid', an Early English Saint's Life (Lewiston, 1992); and M. D. Laynesmith, 'Stephen of Ripon and the Bible: Allegorical and Typological Interpretations of the Life of St Wilfrid', EME 9 (2000), 163-82.

${ }^{42}$ Note the explicit reference to Wilfrid's wealth and power in $V W$ chap. 24 (ed. and trans. Colgrave, pp. 48-9), in which Queen Iurminburh describes 'the temporal glories of St Wilfrid, his riches, the number of his monasteries, the greatness of his buildings, his countless army of followers arrayed in royal vestments and arms' ('sancti Wilfrithi episcopi omnem gloriam eius secularem et divitias necnon coenobiorum multitudinem et aedificiorum magnitudinem innumerumque exercitum sodalium regalibus vestimentis et armis ornatum'). In the context of this chapter, Iurminburh is warning her husband, Ecgfrith, that Wilfrid was a potential threat; Wilfrid, here, embodies the opposite of the 'holy-monk' bishop ideal as highlighted by Cuthbert. For the network of monasteries associated with Wilfrid, see S. Foot, 'Wilfrid's Monastic Empire', in Wilfrid: Abbot, Bishop, Saint, ed. Higham, pp. 27-39, at 33-4. For comments about various secular characteristics found in the VW, see also Goffart, The Narrators, p. 28I; and A. Thacker, 'Wilfrid, His Cult and His Biographer', in Wilfrid: Abbot, Bishop, Saint, ed. Higham, pp. I-I6. D. Pelteret, 'Saint Wilfrid: Tribal Bishop, Civic Bishop of Germanic Lord?', in The Community, the Family and the Saint: 
contains much that is defensive in tone, which is suggestive of the challenges to his authority and position that Wilfrid had to endure. ${ }^{43}$

Despite these different concerns and depictions of their respective heroes, and despite the fact that the $V W$ was written roughly ten years after the $V C A$ had first appeared, Stancliffe has recently emphasised that Stephen's vita was indeed a response to the earlier version by the anonymous Lindisfarne author. This is made particularly apparent by another example of textual engagement: Stephen borrows three passages of text verbatim from the earlier Lindisfarne hagiography. ${ }^{44}$ The first of these borrowings occurs as early as Stephen's preface, enabling the author to conjure the absent presence of Cuthbert into the reader's mind and thereby also to demonstrate that the present vita is a response to the $V C A .{ }^{45}$ Another passage to exhibit borrowing is the account of Wilfrid's election to the bishopric (in 664) in chapter II. $^{46}$ It is surely no coincidence that one principal issue upon which the $V C A$ had structured its account (that of Cuthbert as the perfect example of a bishop) is one of the three occasions where Stephen refers directly to the earlier Life. ${ }^{47}$ It is in itself interesting that just when Stephen wants to prove Wilfrid's readiness and suitability for the episcopal see, he inserts passages taken almost entirely from the earlier VCA. Such borrowing was no doubt intended to guarantee that Wilfrid was just as worthy as Cuthbert of episcopal rank despite his different character and way of life. ${ }^{48}$ Yet there are also subtle differences in terms of the structure and content of these two chapters. The following table sets out in summary form the main elements of the respective chapters in $V C A$ and $V W$ in the order in which they occur in the original texts (the italicised text shows in these instances where the $V W$ borrows directly from the $V C A$ ):

Patterns of Power in Early Medieval Europe, ed. J. Hill and M. Swan (Turnhout, I998), pp. I59-80, esp. 179-80, stresses that Wilfrid had the outlook of a Germanic lord.

43 The $V W$ depicts Wilfrid as going to Rome three times as a result of accusations made against him. See also D. P. Kirby, 'Northumbria in the Time of Wilfrid', in Saint Wilfrid at Hexham, ed. Kirby, pp. I-34.

44 There are three occasions where the $V W$ borrows from the $V C A$, which are all discussed and explored by Stancliffe, 'Dipsuted Episcopacy', who says (at p. I9): 'Without ever naming Cuthbert, it is tantamount to declaring that it is Wilfrid, not Cuthbert, who is the model of the perfect bishop.'

45 The extent of the borrowing is clearly visible in the edition by Colgrave, who has italicised the relevant passages. See also Goffart, The Narrators, pp. 283-4; and Stancliffe, 'Disputed Episcopacy', pp. I4-I5.

46 Again, the extent of borrowing from the $V C A$ is visible in Colgrave's italics. See also Goffart, The Narrators, pp. 283-4.

47 See also Stancliffe, 'Disputed Episcopacy', pp. I5-16.

$4^{8}$ See similarly Thacker, 'Lindisfarne', p. II7. 
Structure of $V C A$ iv. I

Ia. Postquam igitur ab Egfrido rege et episcopis Saxorum omnique senatu deposcenti, ad episcopatum nostrae aecclesiae Lindisfarnensium electus est.

2a. invitus et coactus lacrimans et flens, abstractus est expectante etiam adhuc senatu, cum archiepiscopo Theodoro.

3a. Iam vero post spatium sumpto episcopatu ...

4a. Idem enim constantissime perseverabat, qui prius fuerat.

5a. In omnibus iam observans Pauli apostolici doctrinam, ad Titum dicentem recordatus est.

6a. Ideo namque purus fuit eius sermo, et apertus plenus gravitatis et honestatis, ... cum Domino nostro Iesu Christo accipere mereatur.
Structure of $V W$ chap. II

Ib. Reges deinde consilium cum sapientibus suae gentis post spatium inierunt, quem eligerent in sedem vacantem ... responderunt omnes uno consensu: 'Neminem habemus meliorem et digniorem nostrae gentis quam Wilfrithum presbiterum et abbatem'.

2b. ... quia in omnibus rebus sapientem agnovimus et talem esse, qualem Paulus apostolus ad Titum scribens docuit.

3b. Tunc quoque consenserunt reges et omnis populus huic electioni, et sancto Wilfritho presbitero omnis conventus in nomine Domini accipere gradum episcopalem praecepit. Ille autem primo abnuens, non esse se dignum excusavit; postremo tamen oboediens factus est, noluitque benedictionem Dei effugere.

4b. Qualem ergo illi tunc eum intellexerunt, talem et nos adhuc viventes novimus.

5b. Fuit enim sermo eius purus et apertus, plenus gravitatis et honestatis ... cum Domino nostro Iesu Christo accipere mereatur.

Both chapters begin with the statement that the appropriate authorities all agreed to the election of the relevant holy man; this forms the basis of each. However, the statement in the VCA that Cuthbert was elected 'at the request of King Ecgfrith and the bishops of the Saxons and all the council' (item Ia in the table) seems to act merely as preparation for the emphasis on Cuthbert's humility (item 2a), for one is then told (in part of the chapter not quoted in the table) that Cuthbert had to be persuaded by various select men (including King Ecgfrith, Bishop Tumma and 'chosen men from our community') to accept the position. When eventually Cuthbert does accept, he is led away invitus, coactus, lacrimans and flens, terms that heighten the realism and drama. Most significantly, the reader is informed that Cuthbert 'maintained the dignity of a bishop without abandoning the ideal of the monk or the virtue of the hermit' (implebat episcopi dignitatem non tamen ut propositum monachi et anachoritae uirtutem desereret). 
Although Stephen has deliberately modelled his chapter on that found in the $V C A$, he nonetheless has engineered a certain 'tweaking' of his text that does not advance Wilfrid as a Cuthbert-like figure, as might have been expected in a case of allusion, but which demonstrates the difference in Wilfrid's character. ${ }^{49}$ The emphasis the anonymous author had placed on Cuthbert's election to illustrate that he was humble is absent from this chapter in Stephen; Stephen's aim is partly to stress that Wilfrid's accession to the episcopal see had been legitimate. ${ }^{50}$ Though both accounts begin similarly, the $V W$, careful to stress Wilfrid's legitimacy, adds a phrase that is absent from the $V C A$, that the kings and counsellors consented (responderunt omnes uno consensu): 'We consider that none of our fellow-countrymen is better and more worthy than Wilfrid, priest and abbot' (item Ib). Stephen further emphasises that Wilfrid was the proper choice by inserting the letter of the Apostle Paul to Titus in a more advanced position than in the $V C A$ (item $2 \mathrm{~b}$, and cf. item $5 \mathrm{a}$ ). Again, the reader is informed that the king and all the people agreed to the election of Wilfrid (item $3 \mathrm{~b}$ ). Then, imitating the style of the $V C A$, which had so dramatically portrayed Cuthbert's initial refusal of the bishopric on account of his humility, Wilfrid is described as, at first, excusing himself (abnuens) from the role of bishop. But his refusal is described in terms noticeably brief when compared to those applied to Cuthbert; it is not long before Wilfrid is oboediens (item 3b). These terms are abrupt, as Stephen's focus is not on depicting Wilfrid as a humble 'monk-bishop' but rather on justifying his election and position as bishop and, as Stancliffe has shown, on demonstrating Wilfrid's 'readiness to undertake a public role'. ${ }^{\text {II }}$

The pivotal part that this chapter played in the earlier $V C A$ influenced Stephen to imitate it and, with subtle changes, to try to undermine it. ${ }^{52}$ And Stephen, in an attempt to eradicate the ambiguous reputation of Wilfrid and to justify his position and status, resorts to claims for Wilfrid's defence. This becomes clear in another instance in this chapter where Stephen again can be seen as borrowing. It seems to have been particularly important to the anonymous author that Cuthbert was electus Dei. ${ }^{53}$ In the very first chapter

49 Stancliffe, 'Disputed Episcopacy', pp. I6-I7, shows how 'in his subtle adaptation of the Lindisfarne account, Stephen both presents a different conception of episcopal office as a blessing and as an office that is quite separate from the monastic vocation' (at I7).

so Wilfrid's position was of course not straightforward. After he had been elected to the bishopric for the first time, he departed to Gaul to be consecrated; in his absence, King Oswiu had Chad consecrated in his place ( $V W$ chap. I4). It is little wonder, then, that Stephen took every opportunity to defend Wilfrid's position and appointment as bishop.

51 Stancliffe, 'Disputed Episcopacy', p. I7. $\quad{ }^{52}$ Ibid.

53 See the comments of Stancliffe, 'Cuthbert', p. 25. 
after the two prefaces, the reader meets the phrases Dei electionem and Dei electus. ${ }^{54}$ Now, in the chapter concerning Cuthbert's election to the bishopric, one finds, close together, the two expressions,

ad episcopatum nostrae aecclesiae Lindisfarnensium electus est. Tunc enim supradicto rege et episcopo sanctae memoriae Tumma, et de familia nostra electissimis viris venientibus ad eum. 5

As discussed earlier, this statement regarding Cuthbert's election forms the basis for the VCA's attempt to stress its hero's humility. But, for Stephen, the importance in this repetition resided in the fact that it emphasised Cuthbert's legitimacy, not in the statements of his humility that followed. Thus, when making use of this chapter, Stephen reproduces a form of the repetition of electus but puts it to a different purpose:

Erat autem ita homo ille electus, sicut Iohannes praecursor Domini et Ezechiel propheta, xxx annorum aetatis. Tunc quoque consenserunt reges et omnis populus huic electioni. ${ }^{56}$

Both men are described as being electus, but Cuthbert is so holy, the perfect monk, that he wishes to avoid the wealth and honour associated with being bishop; therefore, it is only through the persuasion of those electissimis viris that he accepts the position; the anonymous author has emphasised Cuthbert's humility and that Cuthbert was truly the right man to be electus. ${ }^{57}$ Despite following the Lindisfarne author in style and content, this allusion in the $V W$ does nothing to further Wilfrid as a Cuthbert-like character; it is merely a method to prove that Wilfrid had indeed been chosen.

Strikingly, the sentence that stands out most, in those lines which Stephen himself wrote and did not borrow, is the one that introduces the passage that concludes the chapter. ${ }^{58}$ This sentence reads, 'Qualem ergo illi tunc eum intellexerunt, talem et nos adhuc viventes novimus' (item

54 VCA i. 3 (ed. and trans. Colgrave, pp. 64-6).

ss 'He was elected to the bishopric of our church at Lindisfarne. For at that time the above-mentioned king [Ecgfrith] and Bishop Tumma of holy memory, and chosen men of our community came to him' ( $V C A$ iv. I (ed. and trans. Colgrave, pp. IIO-II)).

56 'Now this man was elected, like John the forerunner of the Lord and the prophet Ezekial, when thirty years of age. The kings and all the people agreed to this election' ( $V W$, chap. II (ed. and trans. Colgrave, pp. 24-5)).

57 That Cuthbert had been 'chosen' (electus) by the 'chosen men' (electissimis viris) recalls the classical proverb, laudari a laudato viro ('To be praised by a man who himself had received praise'), an expression that itself was used to indicate that the praise received was genuine and could not be bettered. See, for example, Cicero, Letters to Friends 5.I2.7; and in general, R. Tosi, Dizionario delle sentenze latine e greche (Milan, I99I), p. $600 \$ 1333$.

58 Stephen's concluding passage is borrowed verbatim from the Lindisfarne $V C A$. 
4 b), which is translated by Colgrave: 'Their opinion of him in those days did not differ from that of us who are still alive'. A look at the context of this chapter within the vita perhaps helps to explain this remark. The immediately preceding chapter in the $V W$ (chapter Io) describes the conflict (conflictu) that had raged at the Council of Whitby, where Wilfrid had succeeded in his pleas for the Roman party; this chapter ends on a particularly bitter note with Colman, a Lindisfarne man, being forced to retire 'and leave his see to be taken by another and a better man'. It was in this confused aftermath of one of the most heated incidents of the seventh century, ${ }^{59}$ that Alhfrith managed to foster Wilfrid's promotion. ${ }^{60}$ If Wilfrid had been thrust upon the Northumbrian Church, he would have embittered many religious men, especially those he had defeated at Whitby (the Irish party) and then also their close supporters at Lindisfarne. Thus this peculiar sentence provides significant witness to the feelings surrounding Wilfrid. It demonstrates Stephen's realisation that, following his role at Whitby, Wilfrid was by no means universally well received. ${ }^{61}$ Here Stephen wishes to eradicate this low regard for Wilfrid; he emphasises that just as he, the author, can testify that Wilfrid is loved in the present (i.e. at the time Stephen is writing and after Wilfrid has died), he also can prove that Wilfrid had been loved even in the immediate post-Whitby era. In doing so, Stephen makes use of the recent hagiography of one of the celebrated bishops of the time, Cuthbert. And, concerning the very point on which Wilfrid had been controversial (namely, the kind of man that could be a bishop), Stephen borrowed from the earlier vita while making changes that allowed him to demonstrate both how Wilfrid was suited for episcopal office and how his position was legitimate.

\section{The Power of Writing in Early Northumbria}

One of the most controversial episodes in Wilfrid's career is recounted by Stephen in chapters 46 and 47 of the $V W$, when Wilfrid was summoned to a council at Ouestraefelda in the presence of King Aldfrith of Northumbria and Archbishop Berhtwald and 'the bishops of nearly all Britain' (totius

59 For the issues debated at Whitby, see Stancliffe, Bede, Wilfrid, and the Irish.

${ }^{60}$ It is noticeable that Stephen ignores the fact that Tuda was the first to be elected bishop in Colman's place after Whitby, preferring instead to imply that Wilfrid immediately took over. Bede supplies this information about Tuda; HE iii. 26. See also Colgrave, The Life of Bishop Wilfrid, p. I58.

${ }^{6}$ For comments about anti-Wilfridian feeling and the defensive tone of the $V W$, see Thacker, 'Lindisfarne', pp. II9-20. 
paene Brittanniae episcopis). ${ }^{62}$ Stephen describes a meeting in which those present argued with Wilfrid and attempted to deprive him of his possessions and status. In a passage of dramatic prose, Stephen describes how a thegn who was devoted to Wilfrid escaped from Aldfrith's tent and attempted to warn Wilfrid of the plan by those at the council to deceive the bishop. The thegn is made to say:

They are attempting by this treachery to deceive you utterly, in order that at the outset you may confirm by your own signature their sole judgment, so as to support whatever they may settle and decide: so that after you have been bound by this chain of constraint, for the rest you will never be able to make a change afterwards in any way. This will be the upshot of their judgment, that you shall surrender all which you were seen to possess in the land of Northumbria, whether bishopric or monasteries or aught else; and whatever you have gained in Mercia under King Aethilred, you will surrender it all by force to the archbishop that he may give it to whom he wishes; and finally, by condemning yourself you will degrade yourself, by your own signature, from your holy office. ${ }^{63}$

This passage is one of many in the $V W$ in which the importance of written documentation for the justification of land ownership or status is explicitly stated or implicitly stressed. On this occasion, those presiding at the council are attempting to trick Wilfrid into signing something that would later be binding and disadvantageous to him. In other words, by the time Stephen was writing in the early eighth century, written documents such as diplomas and papal privileges were becoming ever more important. Elsewhere in the $V W$ we learn of written judgements that are sent to Rome and there heard by the pope and indeed of papal privileges that are brought back to England as proof of possessions or status and that have been signed and then sealed. ${ }^{64}$ Towards the end of the $V W$, in chapter 60 , we are told of another council, presided over by King Osred of Northumbria, in which both Archbishop Berhtwald and Bishop Wilfrid

${ }^{62}$ For the historical context of this council, see ibid., pp. II6-I7. For the views that these chapters contain about the Irish, see Stancliffe, Bede, Wilfrid, and the Irish.

63 'Hac omnino fraude te moliuntur decipere, ut primitus per scriptionem propriae manus confirmes eorum tantummodo iudicium, quodcunque constituentes diffinient succumbere, ut, postquam isto alligatus fueris districtionis vinculo, de caetero in posterum permutare nullatenus queas. Ista siquidem erit illorum iudicii apertio, ut, quicquid in Ultrahumbrensium aliquando terra possidere visus fuisti vel in episcopatu vel in monasteriis vel in qualibet re, cuncta dimittas; et si quid in Myrciorum regno subsecutus eras sub Aethelredo rege, omnia reddendo archiepiscopo coacte relinquas, ipso donando cui vult; et ad postremum temetipsum dampnando, de tuo te sanctitatis honore cum subscriptione degraderis' ( $V W$ chap. 47 (ed. and trans. Colgrave, pp. 94-7)).

64 See, for example, $V W$ chap. 34. For the importance of canon law in proving Wilfrid's position, see Stancliffe, 'Disputed Episcopacy', pp. 17-I8. 
had brought 'writings from the Apostolic See' (scripta apostolicae sedis) so that they could be read out to those assembled. The importance of these documents was not lost on Berhtfrith, a high-ranking secular official there that day, who requested that a translation of the papal documents be provided.

Given that Stephen felt that documentary evidence was crucial for justifying status and landed possessions, and given that on various occasions he inserts extracts from documents such as papal letters and privileges, it is no surprise to find that in chapter 17 of the $V W$, describing the dedication day of the Ripon church, a large proportion of the second half evokes the language of a diploma. It begins with a reference to the status of those present on the day, which is set out hierarchically and therefore reminiscent of a diploma's witness-list. Stephen also recounts a ceremony whereby Wilfrid, from in front of an altar, read out a list of lands being granted that is at once suggestive of a ceremony of conveyance and the contents of a boundary clause. ${ }^{65}$ Perhaps most tellingly, the reader is informed that the chief men and bishops present gave their signatures to the document, cum consensu et subscriptione, thereby using a formula very similar to a common kind of attestation, consensi et subscripsi. It seems clear that, in this chapter, Stephen inserted language and detail that, if not relying on an actual charter, deliberately recalled the style of such a document. ${ }^{66}$ Stephen intended this legalistic language to prove that the building and endowment of the church for the Wilfridian community were above suspicion. Such formulaic language is unusual in a saint's vita (it is never found in the VCA): that Stephen felt it necessary to resort to it may suggest that he was under pressure to defend and prove what he was saying about Wilfrid.

One can imagine that, in the early days of the Northumbrian Church, ecclesiastical communities would have encountered a degree of competition as each one strove not only to secure its existence (in terms of property, privileges and power) but also to enhance its position. In order to do so, it was natural that these institutions sought to publicise the deeds of their most famous saints, for to be able to boast of a powerful saint helped to guarantee the position of that church in the locality. ${ }^{67}$ This 'hagiographic feud' therefore represents a very early attempt to assert power and status

${ }^{65}$ For the ritual involved in such ceremonies, see D. A. E. Pelteret, 'The Religious Elements in the Textus Roffensis Charters', in Textus Roffensis, ed. O’Brien and Bombi, pp. 29I-3II.

${ }^{66}$ For biblical imagery in this same passage, see Laynesmith, 'Stephen of Ripon', pp. 172-3.

67 Thacker, 'Lindisfarne'. 
through the medium of writing in the Northumbrian kingdom. The individual vitae are crucial witnesses to the ways in which the respective communities sought to place themselves in the wider ecclesio-political world of the late seventh and early eighth centuries. That they do respond to one another may suggest that the authors of these vitae envisaged them having a wider audience than just the ecclesiastical cloister. ${ }^{68}$ Designed to trumpet the saintly credentials of their subjects, the authors may have hoped that these texts could influence powerful secular contemporaries as well as those in the religious hierarchy.

The Lindisfarne community had at various moments been placed in a difficult position by Wilfrid and subsequently by his followers who promoted the memory of Wilfrid. Wilfrid himself had been renowned as an individual intent on building up his network of ecclesiastical houses, and increasing his own wealth and status. He seems also to have taken a keen interest in the evolution of the diplomatic used in Anglo-Saxon charters. ${ }^{69}$ This concern was in some ways only to be expected, for these newly introduced legal documents offered unprecedented levels of security to the holder, in terms of financial and hereditary rights, and any bishop with the kind of portfolio belonging to Wilfrid would have had a vested interest in acquiring that sort of legal documentation. The inclusion of charter language in the $V W$ may suggest that a charter was somehow used as a source of information when describing the foundation of Wilfrid's church at Ripon. But it may also reveal that, in Stephen's mind, it was particularly appropriate to invoke such charter language when describing how Wilfrid built and dedicated his own church at Ripon. The emergence of the $V W$ caused Lindisfarne to have the Vita Cuthberti rewritten by Bede. ${ }^{70}$ But the very particular form of threat posed by Wilfrid and his followers embraced also the use of charters in order to soak up Northumbrian lands and privileges. It is therefore worth considering whether Lindisfarne took precautionary measures other than the publication of a sequence of vitae. Unfortunately, no Northumbrian charters survive from this early period. But when Northumbrian charters do emerge from the tenth century

68 Thacker, 'Wilfrid, His Cult and His Biographer', pp. I3-I4, has some useful comments about Stephen's intended audience being Wilfridian communities, in particular, Ripon and the Mercian houses.

69 P. Sims-Williams, 'St Wilfrid and Two Charters Dated A.D. 676 and 680', JEH 39 (I988), I63-83. For Wilfrid's landed possessions, see M. Roper, 'Wilfrid's Landholdings in Northumbria', in Saint Wilfrid at Hexham, ed. D. P. Kirby (Newcastle upon Tyne, 1975), pp. 6I-79; and G. R. J. Jones, 'Some Donations to Bishop Wilfrid in Northern England', $\mathrm{NH}_{3} \mathrm{I}$ (I995), 22-38.

70 Stancliffe, 'Disputed Episcopacy'. 
onwards, those associated with St Cuthbert's community have a form that is strikingly, and surely pointedly, different from those in use elsewhere in Northumbria. Gone are the formal Latin diplomatic elements and in their stead are brief summaries in Old English of land transactions made directly to St Cuthbert's church and inserted into that community's precious manuscripts. ${ }^{7 \mathrm{I}}$ It is just possible that Lindisfarne, as an off-shoot of the Ionan mission, had encountered such a practice in the Celtic world. ${ }^{72}$ It is also possible that, faced with an acquisitive bishop such as Wilfrid, the Lindisfarne community sought, already in the early eighth century, to distance itself from the use of documents which could be harnessed by that figure to exert pressure and influence over his rivals. In doing so the Cuthbertines would have at once invalidated the documents used by Wilfrid and simultaneously also allowed themselves the ability to operate according to terms dictated by them. Of course, without the survival of early Northumbrian charters, this must remain a hypothesis, but it would have constituted another method of writing power, alongside the use of hagiography, in this formative period of the early Northumbrian Church.

${ }^{71}$ For an account of this practice, see D. A. Woodman, Charters of Northern Houses, AS Charters I6 (Oxford, 2012), pp. 9-I6, 316-35. For the use of charters and diplomas in early Northumbria, see P. Wormald, Bede and the Conversion of England: The Charter Evidence, Jarrow Lecture 1984 (Jarrow, 1985); and I. N. Wood, 'The Gifts of Wearmouth and Jarrow', in The Languages of Gift in the Early Middle Ages, ed. W. Davies and P. Fouracre (Cambridge, 20I0), pp. 89-II5.

72 See, for example, W. Davies, 'The Latin Charter-Tradition in Western Britain, Brittany and Ireland in the Early Mediaeval Period', in Ireland in Early Mediaeval Europe: Studies in Memory of Kathleen Hughes, ed. D. Whitelock, R. McKitterick and D. N. Dumville (Cambridge, 1982), pp. 258-80. 